\title{
Selection of reference genes for quantitative real-time PCR in Casuarina equisetifolia under salt stress
}

\author{
C. FAN*, Z. QIU, B. ZENG, Y. LIU, X. LI, and G. GUO \\ Research Institute of Tropical Forestry, Chinese Academy of Forestry, Guangzhou 510520, P.R. China
}

\begin{abstract}
Real time quantitative PCR (qPCR) is widely used in gene expression analysis for its accuracy and sensitivity. Reference genes serving as endogenous controls are necessary for gene normalization. In order to select an appropriate reference gene to normalize gene expression in Casuarina equisetifolia under salt stress, 10 potential reference genes were evaluated using real time qPCR in the leaves and roots of plants grown under different $\mathrm{NaCl}$ concentrations and treatment durations. GeNorm, NormFinder, and BestKeeper analyses reveal that elongation factor 1-alpha $(E F 1 \alpha)$ and ubiquitin-conjugating enzyme E2 (UBC) were the most appropriate reference genes for real time qPCR under salt stress. However, $\beta$-tubulin $(\beta T U B)$ and actin 7 , which were widely used as reference genes in other plant species, were not

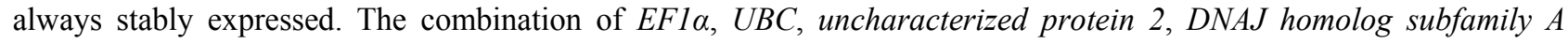
member 2, and glyceraldehyde-3-phosphate dehydrogenase should be ideal reference genes for normalizing gene expression data in all samples under salt stress. It indicates the need for reference gene selection for normalizing gene expression in $C$. equisetifolia. In addition, the suitability of reference genes selected was confirmed by validating the expression of WRKY29-like and expansin-like B1. The results enable analysis of salt response mechanism and gene expression in $C$. equisetifolia.
\end{abstract}

Additional key words: ACT, EF1a, DNAJ, GAPDH, U2, UBC.

\section{Introduction}

Casuarina equisetifolia belongs to the family Casuarinaceae and is predominantly a monoecious species. It is extensively cultivated in coastal areas and on limestone soils near the shores of tropical and subtropical regions for sand stabilization, soil rehabilitation, and as shelter belts (Zhong et al. 2010). C. equisetifolia seedlings survive in a $500 \mathrm{mM} \mathrm{NaCl}$ solution (Tani and Sasakawa 2003), suggesting its high salt tolerance. As woody plants, $C$. equisetifolia shows a long life span and ability to cope with excess salt for extended periods of time. Specific genes mediate salt response in C. equisetifolia. Gene expression analysis is a powerful tool to elucidate the possible mechanisms mediating salt stress and to identify the relevant signal transduction pathways for further prediction of genes with biological functions. Real time quantitative PCR (qPCR) was used extensively to study altered gene expression with a high sensitivity and specificity. However, its reliability depends on stably expressed reference genes (Van Guilder et al. 2008, Bustin et al. 2009). During the past decade, many stable reference genes were screened in plant species such as Arabidopsis thaliana (Czechowski et al. 2005), rice (Jain et al. 2006), Brachypodium distachyon (Hong et al. 2008), wheat (Paolacci et al. 2009), soybean (Libault et al. 2008), tomato (Løvdal and Lillo 2009), and poplar (Xu et al. 2011). However,

Submitted 25 March 2016. last revision 1 July 2016, accepted 12 July 2016.

Abbreviations: ACT - actin 7; $\beta$ TUB - $\beta$-tubulin; Cq - quantification cycle; DNAJ - DNAJ homolog subfamily A member 2; EF1 $\alpha$ - elongation factor 1-alpha; GAPDH - glyceraldehyde-3-phosphate dehydrogenase; GST - glutathione-S-transferase; M - gene expression stability value; MDH - malate dehydrogenase; qPCR - quantitative PCR; U1 - uncharacterized protein 1; U2 - uncharacterized protein 2; UBC - ubiquitin-conjugating enzyme E2.

Acknowledgments: We are grateful to the Ministry of Science and Technology of China (2013AA102705) and the Fundamental Research Funds for central public welfare research institutes (RITFYWZX201304) for financial support. We are also grateful to Dr. Zhang Yong (the Research Institute of Tropical Forestry, Chinese Academy of Forestry, Guangzhou, China) for providing experimental material.

* Corresponding author; e-mail: fancy0417@163.com 
appropriate reference genes have yet to be identified in C. equisetifolia, which prevents further studies investigating gene response to salt stress.

Therefore, this study assessed the stability of 10 candidate reference genes in C. equisetifolia grown under salt stress. These genes included eight traditional housekeeping genes, such as ubiquitin-conjugating enzyme E2 (UBC), glyceraldehyde-3-phosphate dehydrogenase (GAPDH), DNAJ homolog subfamily $A$ member 2 (DNAJ), elongation factor 1-alpha (EF1 $\alpha)$, glutathione-S-transferase (GST), $\beta$-tubulin ( $\beta T U B)$, actin $7(A C T)$, and malate dehydrogenase $(M D H)$, which were used as reference genes in other plant expression studies. These eight candidate reference genes were evaluated for stable expression under five salt treatments in the C. equisetifolia root [SRP064226 in NCBI]. Further, two novel reference genes, uncharacterized protein 1 (U1) and uncharacterized protein 2 (U2), were selected from the transcriptome data of $C$. equisetifolia owing to their stable expression in roots under different durations of salt exposure (SRP064226 in NCBI). The gene sequences were obtained using the assembly of the $C$. equisetifolia root transcriptome sequenced by Illumina high-seq technology. The stability across a large set of samples representing different salt concentrations and treatment durations was compared using statistical and graphical methods. Further, the expressions of WRKY29-like and expansin-like $B 1$ in $C$. equisetifolia subjected to salt stress were examined. This study lays the foundation for further research into gene expression and functional annotation in $C$. equisetifolia.

\section{Materials and methods}

Casuarina equisetifolia J.R. \& G.Forst. clone A8 seedlings were cultured in a growth chamber at a 16-h photoperiod, an irradiance of $200 \mu \mathrm{mol} \mathrm{m} \mathrm{m}^{-2}$, day/night temperatures of $24 / 18{ }^{\circ} \mathrm{C}$, and a relative humidity of $70 \%$ for 8 weeks. Healthy and vigorous seedlings were selected and the plants were transferred to turf soil and irrigated with water containing $\mathrm{NaCl}$ at various concentrations $(0,200$, and $400 \mathrm{mM})$ every $2 \mathrm{~d}$. Four weeks later, the plants showed a clear growth inhibition at $400 \mathrm{mM} \mathrm{NaCl}$. However, the plants showed no visible symptoms of toxicity, except for a slight growth reduction at $200 \mathrm{mM} \mathrm{NaCl}$. Therefore, the plants grown in water for two weeks were transferred to $200 \mathrm{mM} \mathrm{NaCl}$ solutions for $0,1,6,24$, and $168 \mathrm{~h}$. Leaves and roots were harvested and stored at $-80{ }^{\circ} \mathrm{C}$. All the samples were collected and processed in sets of three replicates.

The total RNA was extracted from collected roots and leaves using an RNeasy plant mini kit (Qiagen, Hilden, Germany) according to the manufacturer's instructions. The RNA samples were treated with RNase-free DNaseI (Qiagen) to eliminate residual genomic DNA. The purity and concentration of RNA in the samples were evaluated using a NanoDrop 2000 spectrophotometer (Thermo Fischer Scientific, Wilmington, DE, USA). Samples with concentrations greater than $100 \mathrm{mg} \mathrm{cm}$ and an absorbance $\mathrm{A}_{260} / \mathrm{A}_{280}$ ratio greater than 1.8 were used for cDNA synthesis. Next, $1.0 \mu \mathrm{g}$ of the total RNA was used as a template in real time reactions with SuperScript III reverse transcriptase (Invitrogen, Carlsbad, USA), and cDNA products were diluted 25-fold for real time qPCR.

The sequences of 10 reference genes and 2 salt stress response genes including WRKY29-like and expansinlike $B 1$ were acquired from the assembly of the

C. equisetifolia root transcriptome sequenced using Illumina high-seq technology (SRP064226 in NCBI). Gene primers were designed using the Primer 3 software (http://www.genome.wi.mit.edu/cgi-bin/primer/primer3. cgi). All the primer pairs were initially tested by standard PCR using the Premix Ex Taq (TaKaRa, Tokyo, Japan). The presence of a single amplification product of an expected size for each gene was verified by electrophoresis on a $2.5 \%(\mathrm{~m} / \mathrm{v})$ agarose gel. The real time qPCR reactions were carried out in 96-well blocks with a 7500 real-time PCR system Applied Biosystems (Foster City, USA) using a SYBR® Premix Ex Taq ${ }^{\mathrm{TM}}$ kit (TaKaRa) under conditions recommended by the manufacturer $\left(95^{\circ} \mathrm{C}\right.$ for $30 \mathrm{~s}, 40$ cycles of $95^{\circ} \mathrm{C}$ for $5 \mathrm{~s}$, and $60{ }^{\circ} \mathrm{C}$ for $34 \mathrm{~s}$ ). A dissociation curve was obtained by heating the amplicon from $60{ }^{\circ} \mathrm{C}$ to $95{ }^{\circ} \mathrm{C}$. All the qPCR reactions were carried out in triplicate. The final quantification cycle $(\mathrm{Cq})$ values included the mean of nine values (biological triplicate, each in technical triplicate). Meanwhile, NTC (non-template controls) and a reverse transcription negative control were used for each sample.

To select the best reference gene, the stability of mRNA expression of each candidate gene was statistically analyzed with three different types of software: GeNorm (Vandesompele et al. 2002), NormFinder (Andersen et al. 2004), and BestKeeper (Pfaffl et al. 2004). Quantities of standard RNA were prepared by diluting cDNA $(1 / 5,1 / 25,1 / 125,1 / 625$, and 1/3125; each gene sample in triplicate). Only quantification cycle $(\mathrm{Cq})$ values less than 40 were used to calculate correlation coefficients ( $R^{2}$ values) in Microsoft Excel 2007. 


\section{Results}

To identify the best reference genes for $C$. equisetifolia gene expression, 10 genes including $U B C, G A P D H$, $D N A J, E F 1 \alpha, G S T, \beta T U B, A C T, M D H$, $U 1$, and $U 2$ were selected as candidates in real time qPCR assay based on SYBR green detection (Table 1). The efficiency plots for each of the candidate genes yielded a linear correlation coefficient $\left(R^{2}\right)>0.97$. The specificity of the amplified products was confirmed by the presence of a single band with the expected size for each primer pair in electrophoresis, and single-peak melting curves of the PCR products were identified. Raw expression across all samples revealed a variation between the reference genes (Fig. 1). Quantification cycle values of the 10 genes ranged from 17.7 to 32.9 , the majority of these values ranged between 20 and 25 . The individual reference genes showed different expression ranges across all studied samples. A narrow range of variation in gene expression contributed to a stable gene expression in different samples. The $U B C, E F 1 \alpha, D N A J$, and $U 2$ showed minor variations in expression (below 7 cycles) among the reference genes, whereas $A C T, U 1$, and GST exhibited a much higher variation (above 10 cycles). Further, the wide expression range of the 10 test genes confirms that no single gene was expressed constantly in all the samples. Therefore, selection of a reliable reference gene for normalizing gene expression under salt stress in C. equisetifolia was imperative.

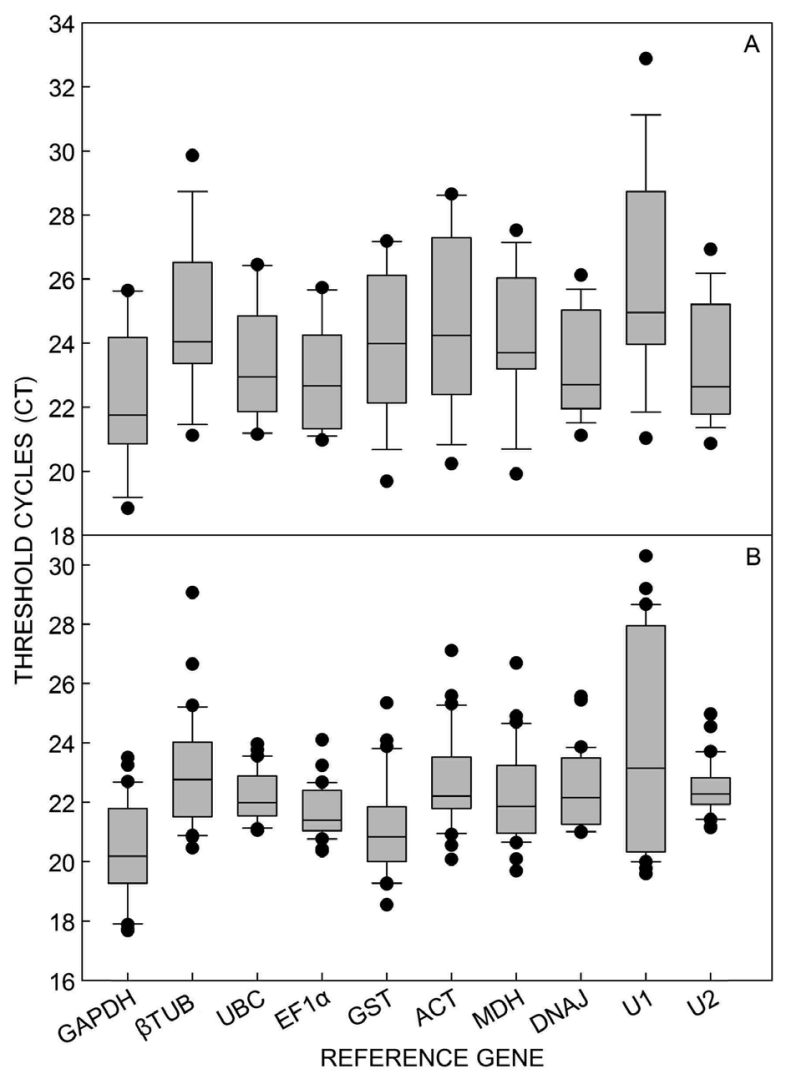

Fig. 1. Absolute CT values of following quantitative PCR of samples. $A$ - Leaves and roots treated with different $\mathrm{NaCl}$ concentrations $(n=18) ; B$ - Leaves and roots treated with $200 \mathrm{mM} \mathrm{NaCl}$ at different treatment duration $(n=30)$. Each box indicates $25 / 75$ percentiles. Whisker caps represent $10 / 90$ percentiles. The median is depicted by lines and dots represent outliers of the $10^{\text {th }} / 90^{\text {th }}$ percentiles. GAPDH - glyceraldehyde-3-phosphate dehydrogenase, $\beta$ TUB - $\beta$-tubulin, UBC - ubiquitin-conjugating enzyme E2, EF1 $\alpha$ - elongation factor 1-alpha, GST - glutathione-S-transferase, ACT - actin 7, MDH - malate dehydrogenase, DNAJ - DNAJ homolog subfamily A member 2, U1 - uncharacterized protein 1, U2 - uncharacterized protein 2.

GeNorm, NormFinder, and BestKeeper were used to analyze the stability of the tested genes in $C$. equisetifolia leaves and roots. GeNorm assumes that the expression ratio of two ideal reference genes is stable in a given sample set. The gene expression stability value $(\mathrm{M})$ is calculated for all genes under investigation and a lower $\mathrm{M}$ value indicates a higher stability (Vandesompele et al. 2002). Under different $\mathrm{NaCl}$ concentrations, DNAJA2 and $E F 1 \alpha$ were the most stable genes with values of 0.482 , whereas $A C T 7$ and $U 1$ were the least stable with values ranging from 0.944 to 1.16 (Fig. $2 A$ ). Under the different salt duration treatments, $U B C$ and $E F 1 \alpha$ were the most 
stable genes, whereas $G S T$ and $U 1$ were the least (Fig. 2B). When all samples were analyzed together, $U B C$ and $E F 1 \alpha$ with an $\mathrm{M}$ value of 0.436 were the most stable, whereas GST and $U 1$ were the least stable (Fig. 2C). In addition, almost all of the tested reference genes (except $U 1)$ showed a relatively high stability with $\mathrm{M}$ values less than the default limit of $\mathrm{M} \leq 1.5$.

In this study, pairwise variation $(\mathrm{Vn} / \mathrm{Vn}+1)$ between the sequential normalization factors (NF) (NFn and NFn+1) was calculated using GeNorm to determine the optimal number of reference genes. It was unnecessary to include an additional reference gene when the cut-off value was less than 0.15 according to recommendations of Vandesompele et al. (2002). As shown in Fig. 1 Suppl., when all samples were considered together to determine the optimal number of reference genes, the pairwise variations in the $\mathrm{V} 2 / 3, \mathrm{~V} 3 / 4$, and $\mathrm{V} 4 / 5$ values were $0.187,0.16$, and 0.202 , respectively, whereas the pairwise variation in the V5/6 value was 0.148 . The results indicate that $E F 1 \alpha, U B C, U 2, D N A J$, and $G A P D H$ were ideal reference genes for normalizing gene expression in all the samples. However, analysis of the pairwise variation with the different salt concentration treatments reveals that three reference genes EFI $\alpha$, $D N A J$, and $U 2$ were sufficient to normalize the expression of target genes. Under the different salt duration treatments, the five genes $(E F 1 \alpha, U B C, U 2$, $D N A J$, and $G A P D H)$ were required for normalization. Therefore, the three to five most stably expressed genes, mentioned above for each type of samples, were selected as reference genes.

Table 1. Real time quantitative PCR analysis of candidate genes (for explanation of the gene abbreviations see Fig. 1) from Casuarina equisetifolia.

\begin{tabular}{|c|c|c|c|c|c|c|}
\hline Gene & $\begin{array}{l}\text { Acc. number } \\
\text { and length }\end{array}$ & Gene description & $\begin{array}{l}\text { Arabidopsis } \\
\text { ortholog locus }\end{array}$ & Primer pair (forward/reverse) & $\begin{array}{l}\text { Product } \\
\text { size and } \\
\text { position }\end{array}$ & $R^{2}$ \\
\hline$G A P D H$ & $\begin{array}{l}\text { comp } 97785 \\
(594 \mathrm{bp})\end{array}$ & $\begin{array}{l}\text { glyceraldehyde-3-phosphate } \\
\text { dehydrogenase }\end{array}$ & AT & $\begin{array}{l}\text { CGGCCTTTTCCTTGTCAGTG } \\
\text { GTCAAGGACTCCAATACCCTTCT }\end{array}$ & $\begin{array}{l}145 \mathrm{bp} \\
(156-300)\end{array}$ & 0.984 \\
\hline DNAJA2 & $\begin{array}{l}\text { comp148822 } \\
(1926 \mathrm{bp})\end{array}$ & $\begin{array}{l}\text { DNAJ homolog subfamily A } \\
\text { member } 2\end{array}$ & AT3G44110 & $\begin{array}{l}\text { CATTGTGCCGTGCTGAAACC } \\
\text { TGAAGATTGAGTGTTAACGAGGTG }\end{array}$ & $\begin{array}{l}132 b p \\
(14-145)\end{array}$ & 0.992 \\
\hline$E F 1 \alpha$ & $\begin{array}{l}\text { comp } 109215 \\
(516 \mathrm{bp})\end{array}$ & elongation factor 1 -alpha & AT1G07940 & $\begin{array}{l}\text { TGGCATGTACTTGAGGATCACA } \\
\text { TGCATTGATGGCACGAAGC }\end{array}$ & $\begin{array}{l}148 \mathrm{bp} \\
(11-132)\end{array}$ & 0.978 \\
\hline$U B C$ & $\begin{array}{l}\text { comp131250 } \\
(1160 \mathrm{bp})\end{array}$ & conjugating & AT3G57870 & $\begin{array}{l}\text { CCATGGTGTACTCTCTCTGCC } \\
\text { TGTTTTGTGATAAGGATTACCCAGA }\end{array}$ & $\begin{array}{l}147 \mathrm{bp} \\
(601-747)\end{array}$ & 0.994 \\
\hline$G S T$ & $\begin{array}{l}\text { comp } 143368 \\
(1213 \mathrm{bp})\end{array}$ & glutathione-S-transferase & AT1G02930 & $\begin{array}{l}\text { GGCACCAGTAACCACAAAAGC } \\
\text { CGGTGGCCTATCTGGGGTAT }\end{array}$ & $\begin{array}{l}132 \mathrm{bp} \\
(61-192)\end{array}$ & 0.982 \\
\hline$U 1$ & $\begin{array}{l}\text { comp168148 } \\
(1120 \mathrm{bp})\end{array}$ & uncharacterized protein & No hit & $\begin{array}{l}\text { TCCATCCATGACTGTTTTGTTTT } \\
\text { TGGGTCAAATCTAGCTTGCCT }\end{array}$ & $\begin{array}{l}143 \mathrm{bp} \\
(301-443)\end{array}$ & 0.972 \\
\hline$U 2$ & $\begin{array}{l}\text { comp } 135147 \\
(1046 \mathrm{bp})\end{array}$ & $\begin{array}{l}\text { translationally-controlled } \\
\text { tumor protein }\end{array}$ & No hit & $\begin{array}{l}\text { GTGTCAACAACTTGATGTACCTCTT } \\
\text { GTGGAGGTGAGGATGAGGGT }\end{array}$ & $\begin{array}{l}139 \mathrm{bp} \\
(603-741)\end{array}$ & 0.971 \\
\hline$\beta T U B$ & $\begin{array}{l}\text { comp } 156426 \\
(2082 \mathrm{bp})\end{array}$ & tubulin beta & AT1G20010 & $\begin{array}{l}\text { GGTGCTGGAAACAATTGGGC } \\
\text { GACAGTCACAGTTCTCAGCCT }\end{array}$ & $\begin{array}{l}103 b p \\
(410-512)\end{array}$ & 0.988 \\
\hline$A C T 7$ & $\begin{array}{l}\text { comp150391 } \\
(2020 \mathrm{bp})\end{array}$ & $\operatorname{actin} 7$ & AT5G09810 & $\begin{array}{l}\text { TCTATGAAGGATATGCCCTCCC } \\
\text { GGACAATTTCCCGTTCGGC }\end{array}$ & $\begin{array}{l}135 \mathrm{bp} \\
(858-992)\end{array}$ & 0.992 \\
\hline$M D H$ & $\begin{array}{l}\text { comp148486 } \\
(1658 \mathrm{bp})\end{array}$ & malate dehydrogenase & AT3G47520 & $\begin{array}{l}\text { GTTGTTGAGGCTTGCACTGG } \\
\text { CAGCTGCATGCTTTTCGAGG }\end{array}$ & $\begin{array}{l}145 \mathrm{bp} \\
(453-597)\end{array}$ & 0.992 \\
\hline $\begin{array}{l}\text { WRKY29 } \\
\text { like }\end{array}$ & $\begin{array}{l}\text { Comp151289 } \\
(1771 \mathrm{bp})\end{array}$ & WRKY transcript factor 29 & AT4G23550 & $\begin{array}{l}\text { TGGGCACCGAATTCTTTCCA } \\
\text { GTCCCAGAAGCAACCATCCA }\end{array}$ & $\begin{array}{l}80 \mathrm{bp}(1381 \\
-1460)\end{array}$ & 0.994 \\
\hline $\begin{array}{l}\text { expansin- } \\
\text { like } B 1\end{array}$ & $\begin{array}{l}\text { - Comp149703 } \\
\text { (1291 bp) }\end{array}$ & expansin-like B1 & AT4G17030 & $\begin{array}{l}\text { GCGTGTGAAAGTGCCTTGAG } \\
\text { TTGAGACATGGGGTTCGCAA }\end{array}$ & $\begin{array}{l}97 b p(1127 \\
-1223)\end{array}$ & 0.993 \\
\hline
\end{tabular}

The stability of expression was then re-analyzed using the NormFinder algorithm that is based on minimal combined inter- and intra-group variations in gene expression for normalization factor (NF) calculation (Andersen et al. 2004). Similarly to GeNorm analysis, a lower average expression stability indicated a more stable gene expression (Fig. 3). Ranking reference genes showed a minimal difference from that of the GeNorm software. When the $C$. equisetifolia seedlings were subjected to various $\mathrm{NaCl}$ concentrations and durations of
$200 \mathrm{mM} \mathrm{NaCl}$ treatment, GAPDH always emerged as the most stably expressed gene, whereas it was ranked fourth and sixth by GeNorm, respectively. However, $U B C$, $E F 1 \alpha$, and $U 2$ showed a rather stable expression both under varying salt concentrations and under treatment durations, similar to the results of GeNorm.

BestKeeper analysis is another applet, which was used to analyze raw $\mathrm{Cq}$ data to determine the most stable genes based on the standard deviation (SD) and coefficient of variance $(\mathrm{CV})$. Genes with the lowest values of $\mathrm{SD}$ were 
classified as the most stable (Pfaffl et al. 2004). The results were similar to the GeNorm and NormFinder programs (Fig. 4). The $E F 1 \alpha, U 2$, and $U B C$ were always considered the most stable among the 10 genes in all the experimental samples. Similarly, the least stable genes $U 1, A C T$, and $\beta T U B$ were observed under the different salt duration and $\mathrm{NaCl}$ concentration datasets. However, slightly altered rank orders were observed. For example, GAPDH was ranked sixth by BestKeeper, whereas it emerged as the most stable in NormFinder analysis in all the samples.

To obtain appropriate reference genes, ranking orders of candidate genes by BestKeeper, NormFinder, and GeNorm were comprehensively analyzed. In summary, irrespective of the ranking order (Table 2), EF $1 \alpha, U B C$, and $U 2$ were the most appropriate reference genes to normalize mRNA levels within the context of different $\mathrm{NaCl}$ concentrations and treatment durations. Conversely, $M D H, \beta T U B, G S T, A C T$, and U1 showed relatively low expression stabilities in the leaves and roots of C. equisetifolia exposed to salt stress.

The expression of WRKY29-like and expansin-like $B 1$ genes under salt stress was analyzed using selected reference genes $U B C, E F 1 \alpha, U 2, D N A J$, and $G A P D H$ in
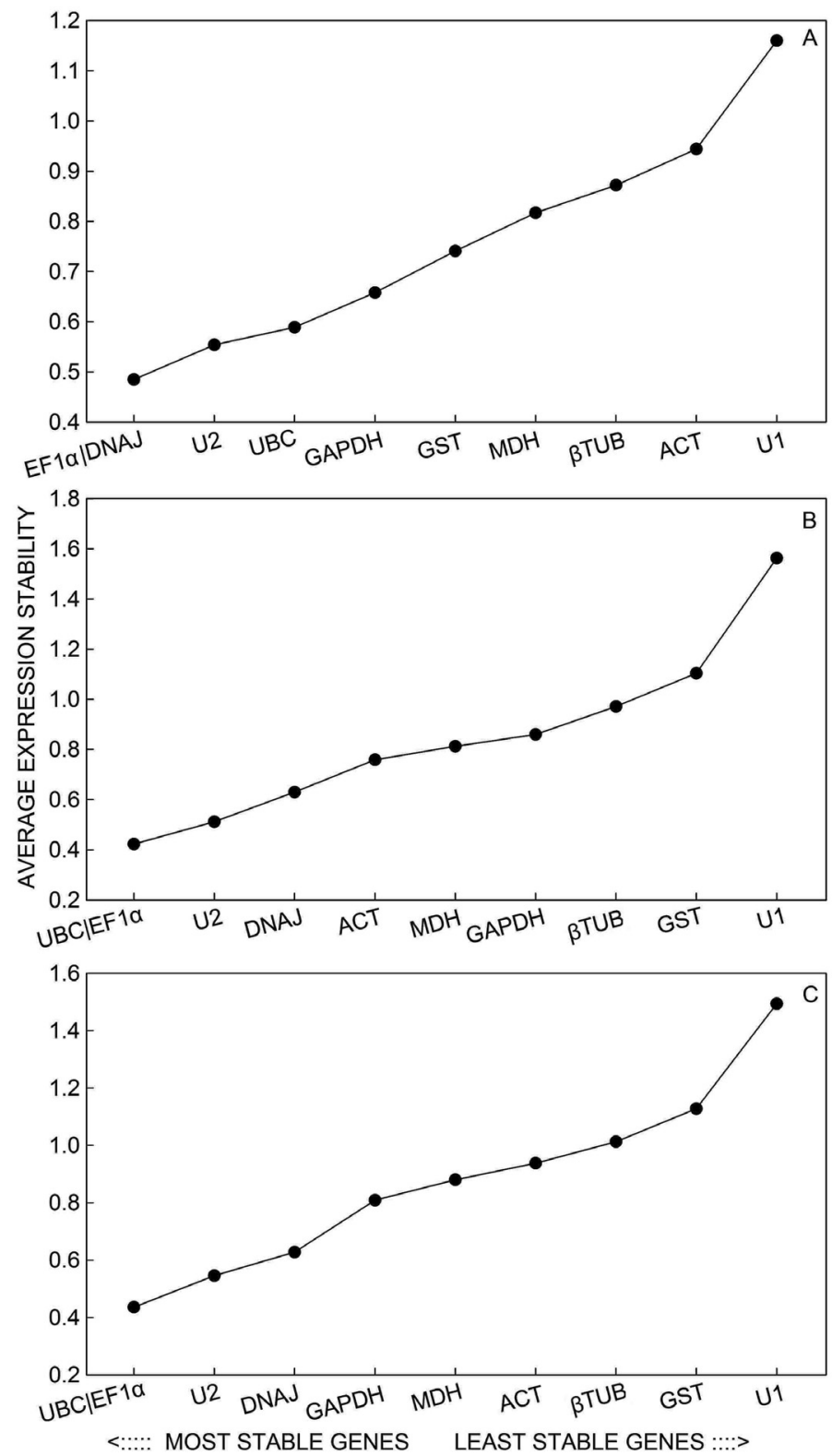

Fig. 2. Stability of average expression and ranking 10 candidate reference genes (for explanation of the gene abbreviations see Fig. 1) calculated by GeNorm: $A$ - different $\mathrm{NaCl}$ concentrations $(n=18), B$ - different treatment durations $(n=30), C$ - all samples $(n=48)$. Lower average expression stabilities (M values) indicate a higher stability. 
Table 2. The ranking order of reference genes (for explanation of the gene abbreviations see Fig. 1) using BestKeeper, NormFinder, and GeNorm algorithms.

\begin{tabular}{lllllllllll}
\hline & EF1 & UBC & U2 & DNAJ & GAPDH & MDH & ACT & $\beta T U B$ & GST & U1 \\
\hline GeNorm & 1.5 & 1.5 & 3 & 4 & 5 & 6 & 7 & 8 & 9 & 10 \\
NormFinder & 3 & 2 & 4 & 7 & 1 & 6 & 5 & 9 & 8 & 10 \\
BestKeeper & 1 & 3 & 2 & 4 & 6 & 5 & 8 & 7 & 9 & 10 \\
Mean rank & 1.83 & 2.17 & 3 & 5 & 4 & 5.67 & 6.67 & 8 & 8.67 & 10 \\
\hline
\end{tabular}
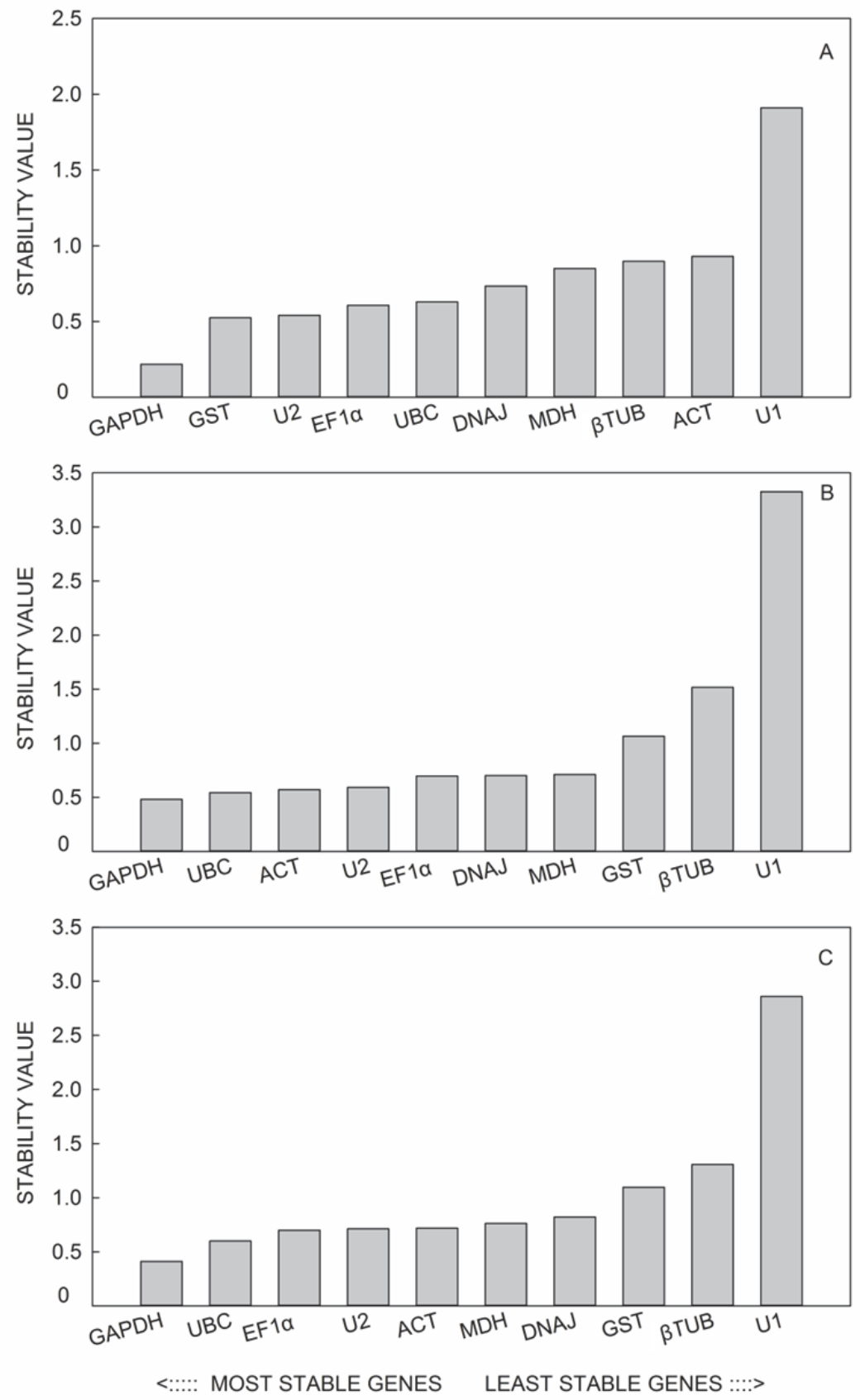

Fig. 3. Stability of Casuarina equisetifolia candidate reference genes (for explanation of the gene abbreviations see Fig. 1) using NormFinder: $A$ - different $\mathrm{NaCl}$ concentrations $(n=18), B$ - different treatment durations $(n=30), C$ - all samples $(n=48)$. A lower stability value indicates more stable expression. 
combination (Fig. 5A,B). The WRKY29-like gene was slightly down-regulated in roots with no obvious change in leaves under the increasing $\mathrm{NaCl}$ concentration. However, the abundance of WRKY29-like mRNA increased rapidly and peaked after $1 \mathrm{~h}$ of the treatment in roots and increased dramatically only after $168 \mathrm{~h}$ of the treatment in leaves (Fig. 5A). The abundance of expansin-like B1 mRNA was obviously down-regulated with the increasing $\mathrm{NaCl}$ concentration in leaves and roots. The expansin-like B1 expressions were enhanced eventually with the salt treatment and peaked after $168 \mathrm{~h}$ (Fig. 5B). Further, the expressions of the
WRKY29-like gene and expansin-like B1 under the salt stress were analyzed using $U B C$ individually (Fig. $5 C, D)$. The relative expression profiles of the WRKY29like and expansin-likeB1 genes in leaves and roots showed similar trends when the reference gene $U B C$ was used at the different $\mathrm{NaCl}$ concentrations and treatment durations. However, the differences in expression of the WRKY29-like gene at the different concentrations of $\mathrm{NaCl}$ persisted (Fig. 5C). Overall, the results show that selection of appropriate reference genes is essential for accuracy and normalization using real time qPCR.
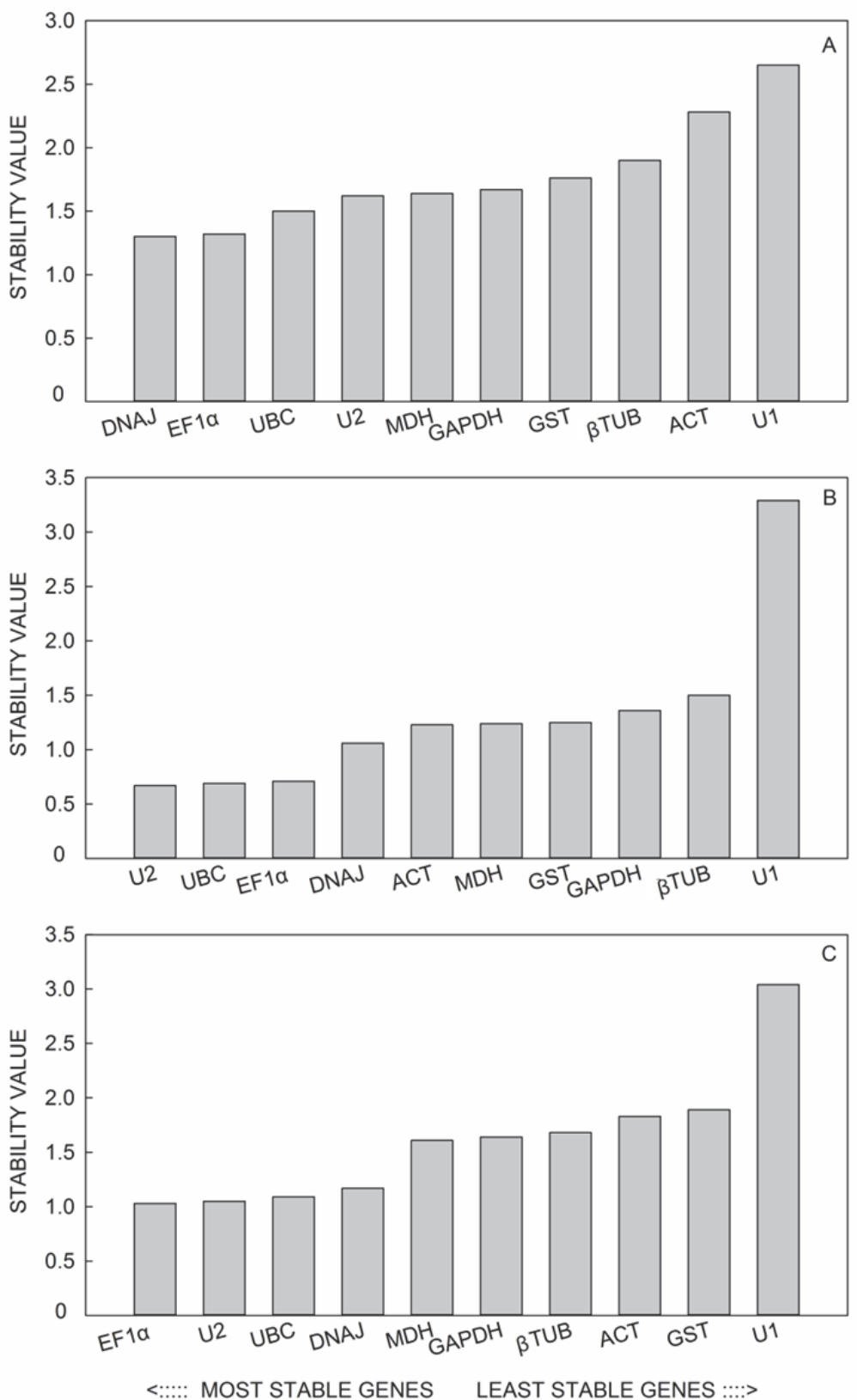

Fig. 4. Stability of Casuarina equisetifolia candidate reference genes (for explanation of the gene abbreviations see Fig. 1) using BestKeeper: $A$ - different $\mathrm{NaCl}$ concentrations $(n=18), B$ - different treatment durations $(n=30), C$ - all samples $(n=48)$. A lower stability value indicates more stable expression. 


\section{Discussion}

In plant molecular biology, studies in C. equisetifolia mainly focused on gene identification during nitrogen fixation (Obertello et al. 2007, Peter et al. 2007). No study investigated the response and adaptation of this species to salinity although $C$. equisetifolia seedlings survive in a $500 \mathrm{mM} \mathrm{NaCl}$ solution (Tani and Sasakawa 2003). To unravel the complex molecular mechanisms and expression patterns of genes mediating adaption to saline stress, identification of stably expressed reference genes is essential.

Previous studies demonstrated that a single gene is not always expressed stably under all experimental conditions and in all plant species. In this study, $\beta T U B$ and $A C T$, which are frequently used as internal control genes in many experiments (Czechowski et al. 2005, De Oliveira et al. 2012, Kumar et al. 2013, Hu et al. 2014), were not stably expressed under the experimental setting using the complementary algorithms (GeNorm, NormFinder, and BestKeeper). The GAPDH, which is expressed stably in sugarcane, poplar, and other species, showed a high variation in expression and was not suitable as an internal control (Xu et al. 2011, Ling et al. 2014). Surprisingly, U2, which encoded an unknown protein and was expressed stably in transcriptome analysis (unpublished data), showed comparatively a less variability and acceptable stability. It was also expressed in Arabidopsis thaliana and Eucalyptus grandis when selecting the best reference gene based on both real time qPCR and microarray (Czechowski et al. 2005, De Oliveira et al. 2012). These results indicate that a reference gene selected in one organism may not express stably in another organism under a given set of conditions and hence, validation of a housekeeping gene is essential. In this study, several candidate reference genes, such as

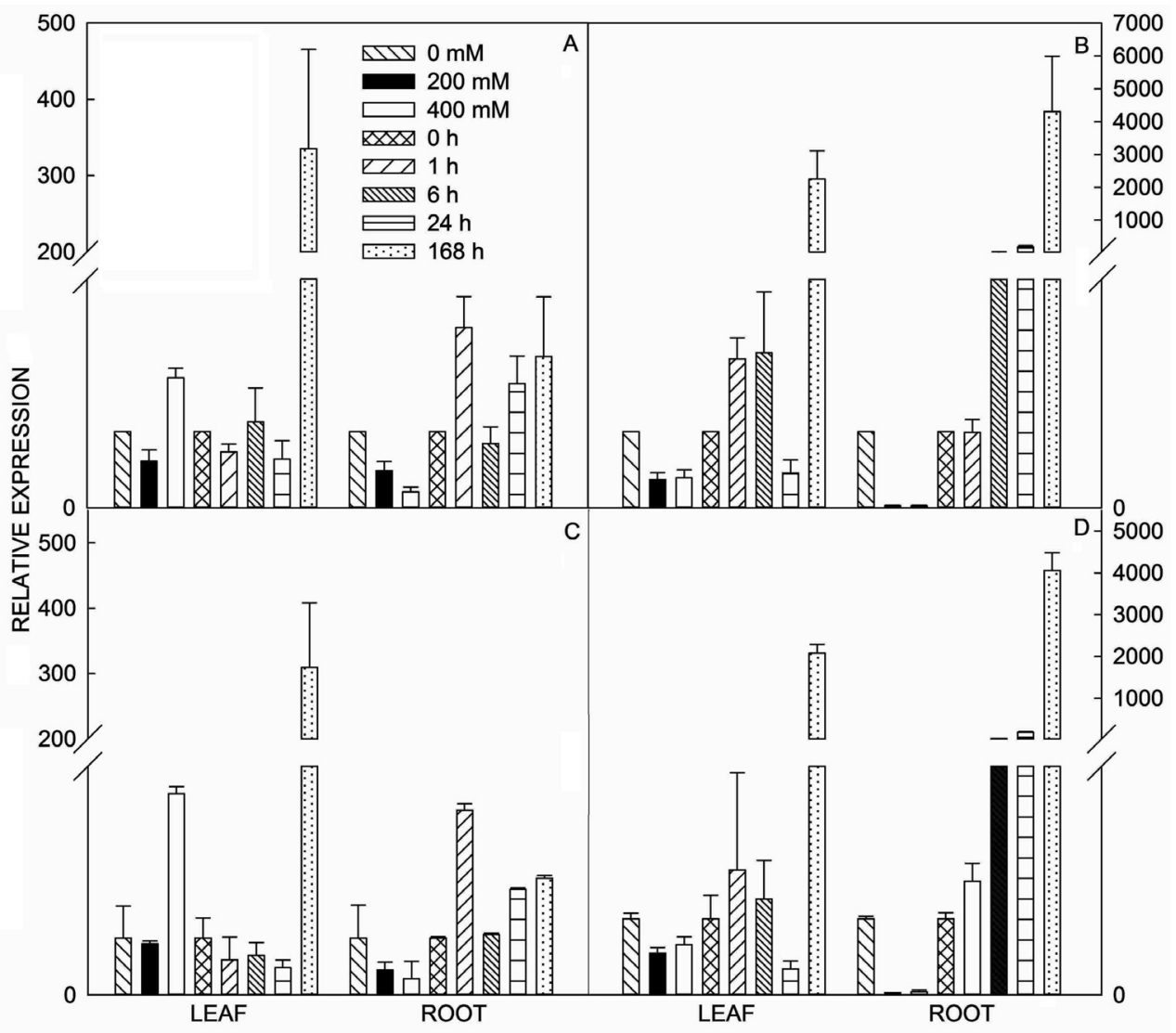

Fig. 5. Quantification of relative expression of WRKY29-like and expansin-like B1 genes using selected reference genes ubiquitinconjugating enzyme E2 (UBC), elongation factor 1-alpha, uncharacterized protein 2, DNAJ homolog subfamily A member 2, and glyceraldehyde-3-phosphate dehydrogenase in combination $(A, B)$ and with $U B C$ individually $(C, D)$. A,C - WRKY29-like gene expression at different $\mathrm{NaCl}$ concentrations and treatment durations; $B, D$ - expansin-like $B 1$ gene expression at different $\mathrm{NaCl}$ concentrations and treatment durations.

$G S T, U 1$, and $M D H$, which were expressed stably in roots at different durations of $\mathrm{NaCl}$ treatment by previous transcriptome analysis (unpublished data), showed differential expressions in leaves or at different $\mathrm{NaCl}$ concentrations. However, $E F 1 \alpha$ and $U B C$ performed well in all the three algorithms and therefore were identified as 
the most appropriate reference genes, consistent with validated reference genes in other species such as rice, sugarcane, and Cocos nucifera (Czechowski et al. 2005, Jain et al. 2006, Ling et al. 2014, Saraiva et al. 2014, Xia et al. 2013). Further, a single reference gene may not be reliable and two or more internal reference genes are needed for accurate and reliable results. Pairwise variation results in this study were verified. Under different $\mathrm{NaCl}$ concentrations, three reference genes were necessary to normalize gene expression. At different salt durations, five genes were required for normalization following stable expression in roots. The results also indicate that many genes including a few housekeeping genes were unstable under salt stress. Therefore, additional internal reference genes were required. Further, ranking by the different softwares varied, especially in the genes ranking the top. The GAPDH was the most stable gene when NormFinder was used. However, GeNorm and Bestkeeper ranked GAPDH as less stable. GeNorm and BestKeeper showed more consistency compared with NormFinder in ranking the candidate reference genes. This discrepancy in ranking by the three software programs was observed in bamboo (Fan et al. 2013) and tung tree (Han et al. 2012)), which was mainly attributed to different algorithms.

The WRKY family contains nearly 100 members in Arabidopsis, some of which appear to mediate plant response to biotic and abiotic stresses (Eulgem et al. 2000, Xu et al. 2006, Hsu et al. 2013, Wang et al. 2014). The WRKY29/22 is induced in plant response to both bacterial and fungal infection, and its expression in transiently transformed leaves reduces disease symptoms (Asai et al. 2002). Expression of WRKY15 induces endoplasmic reticulum-to-nucleus communication leading to disrupted mitochondrial stress response under salt stress during plant growth (Vanderauwera et al. 2012). Many WRKY genes are strongly and rapidly induced during response to various abiotic stresses (Hsu et al. 2013). In this study, WRKY 29-like gene expression was rapidly enhanced in response to salt stress. Expansin represents a cell wall loosening protein and mediates cell wall extensibility. Increasing evidence suggests that expansin plays an essential role in response to salt stress. In a salt-resistant maize cultivar, $\beta$-expansin transcription is higher than in a sensitive cultivar (Geilfus et al. 2010). Meanwhile, the abundances of $\beta$-expansin, AtEXP3, and $A t E X P-B 1$ transcription vary under salt stress (Buchanan et al. 2005, Kwon et al. 2008). Expression of expansinlike $B 1$ was enhanced gradually with increasing $\mathrm{NaCl}$ treatment duration in this study, similarly to EXPA1 and EXLB1 expressions in Jatropha curcas seedlings exposed to salt stress (Zhang et al. 2014). These results also indicate the stability and reliability of the selected reference genes.

\section{References}

Andersen, C.L., Jensen, J.L., Ørntogt, T.F.: Normalization of real-time quantitative reverse transcription-PCR data: a model-based variance estimation approach to identify genes suited for normalization, applied to bladder and colon cancer data sets. - Cancer Res. 64: 5245-5250, 2004.

Asai, T., Tena, G., Plotnikova, J., Willmann, M.R., Chiu, W. L., Gomez-Gomez, L., Boller, T., Ausubel, F.M., Sheen, J.: MAP kinase signalling cascade in Arabidopsis innate immunity. - Nature 415: 977-983, 2002.

Buchanan, C.D., Lim, S., Salaman, R.A., Kagiampakis, I., Morishige, D.T., Weers, B.D., Klein, R.R., Pratt, L.H., Cordonnier-Pratt, M.M., Klein, P.E., Mullet, J.E.: Sorghum bicolor's transcriptome response to dehydration, high salinity and ABA. - Plant mol. Biol. 58: 699-720, 2005.

Bustin, S.A., Benes, V., Garson, J.A., Hellemans J., Huggett, J., Kubista, M., Mueller, R., Nolan, T., Pfaffl, M.W., Shipley, G.L., Vandesompele, J., Wittwer, C.T.: The MIQE guidelines: minimum information for publication of quantitative real-time PCR experiments. - Clin. Chem. 55: 611-622, 2009.

Czechowski, T., Stitt, M., Altmann, T., Udvardi M.K., Scheible W.R.: 2005 Genome-wide identification and testing of superior reference genes for transcript normalization in Arabidopsis. - Plant Physiol. 139: 5-17, 2005.

De Oliveira, L.A., Breton, M.C., Bastolla, F.M., Camargo Sda, S., Margis, R., Frazzon, J., Pasquali, G.: Reference genes for the normalization of gene expression in Eucalyptus species. - Plant Cell Physiol. 53: 405-422, 2012.
Eulgem, T., Rushton, P.J., Robatzek, S., Somssich, I.E.: The WRKY superfamily of plant transcription factors. - Trends Plant Sci. 5: 199-206, 2000.

Fan, C., Ma, J., Guo, Q., Li, X., Wang, H., Lu, M.: Selection of reference genes for quantitative real-time PCR in bamboo (Phyllostachys edulis). - PLoS ONE. 8: e56573, 2013.

Geilfus, C.M., Zorb, C., Muhling, K.H.: Salt stress differentially affects growth-mediating $\beta$-expansins in resistant and sensitive maize ( Zea mays L.). - Plant Physiol. Biochem. 48: 993-998, 2010.

Han, X., Lu, M., Chen, Y., Zhan, Z., Cui, Q., Wang, Y.: Selection of reliable reference genes for gene expression studies using real-time PCR in tung tree during seed development. - PLoS ONE 7: e43084, 2012.

Hong, S.Y., Seo, P.J., Yang, M.S., Xiang, F., Park, C.M.: Exploring valid reference genes for gene expression studies in Brachypodium distachyon by real-time PCR. - BMC Plant Biol. 8: 112, 2008.

Hsu, F.C., Chou, M.Y., Chou, S.J., Li, Y.R., Peng H.P., Shih, M.C.: Submergence confers immunity mediated by the WRKY22 transcription factor in Arabidopsis. - Plant Cell 25: 2699-2713, 2013.

Hu, Y., Chen, H., Luo, C., Dong, L., Zhang, S., He, X., Huang, G.: Selection of reference genes for real-time quantitative PCR studies of kumquat in various tissues and under abiotic stress. - Sci. Hort. 174: 207-216, 2014.

Jain, M., Nuhawan, A., Tyagi, A.K., Khurana, J.P.: Validation of housekeeping genes as internal control for studying gene 
expression in rice by quantitative real-time PCR. - Biochem. biophys. Res. Commun. 345: 646-651, 2006.

Kumar, K., Muthamilarasan, M., Prasad, M.: Reference genes for quantitative real-time PCR analysis in the model plant foxtail millet (Setaria italica L.) subjected to abiotic stress conditions. - Plant Cell Tissue Organ Cult. 115: 13-22, 2013.

Kwon, Y.R., Lee, H.J., Kim, K., Hong, S.W., Lee, S.J., Lee, H.: Ectopic expression of Expansin3 or Expansin $\beta 1$ causes enhanced hormone and salt stress sensitivity in Arabidopsis. - Biotechnol. Lett. 30: 1281-1288, 2008.

Løvdal, T., Lillo, C.: Reference gene selection for quantitative real-time PCR normalization in tomato subjected to nitrogen, cold, and light stress. - Anal. Biochem. 387: 238242, 2009.

Libault, M., Thibivilliers, S., Bilgin, D., Radwan, O., Benitez, M., Clough, S.J., Stacey, G.: Identification of four soybean reference genes for gene expression normalization. - Plant Genome 1: 44-54, 2008.

Ling, H., Wu, Q., Guo, J., Xu, L., Que, Y.: Comprehensive selection of reference genes for gene expression normalization in sugarcane by real time quantitative RTPCR. - PLoS ONE. 9: e97469, 2014.

Obertello, M., Wall, L., Laplaze, L., Nicole, M., Auguy, F., Gherbi, H., Bogusz, D., Franche, C.: Functional analysis of the metallothionein gene cgMT1 isolated from the actinorhizal tree Casuarina glauca. - Mol. Plant-Microbe Interact. 20: 1231-1240, 2007.

Peter, B., Swarup, R., Jansen, L., Devos, G., Auguy, F., Collin, M., Santi, C., Hocher, V., Franche, C., Bogusz, D., Bennett, M., Laplaze, L.: Auxin influx activity is associated with frankia infection during actinorhizal nodule formation in Casuarina glauca. - Plant Physiol. 144: 1852-1862, 2007.

Paolacci, A.R., Tanzarella, O.A., Porceddu E., Ciaffi, M.: Identification and validation of reference genes for quantitative RT-PCR normalization in wheat. - BMC mol. Biol. 10: 11, 2009.

Pfaffl, M.W., Tichopad, A., Prgomet, C., Neuvians, T.P.: Determination of stable housekeeping genes, differentially regulated target genes and sample integrity: BestKeeperExcel-based tool using pair-wise correlations. - Biotechnol. Lett. 26: 509-515, 2004.

Saraiva, K.C., Fernandes de Melo, D., Morais, V., Vasconcelos, I., Costa, J.: Selection of suitable soybean EF1 $1 \alpha$ genes as internal controls for real-time PCR analyses of tissues during plant development and under stress conditions. Plant cell. rep. 33: 1453-1465, 2014.

Tani, C., Sasakawa, H.: Salt tolerance of Casuarina equisetifolia and FrankiaCeq1 strain isolated from the root nodules of C. equisetifolia. - Soil Sci. Plant Nutr. 49: 215222, 2003.

Vanderauwera, S., Vandenbroucke, K., Inze, A., Van de Cotte, B., Muhlenbock P., De Rycke, R., Naouar, N., Van Gaever, T., Van Montagu, M.C., Van Breusegem, F.: AtWRKY15 perturbation abolishes the mitochondrial stress response that steers osmotic stress tolerance in Arabidopsis. - Proc. nat. Acad. Sci. USA 109: 20113-20118, 2012.

Vandesompele, J., De Preter, K., Pattyn, F., Poppe, B., Van Roy, N., De Paepe, A., Speleman, F.: Accurate normalization of real-time quantitative RT-PCR data by geometric averaging of multiple internal control genes. - Genome Biol. 3: 503515, 2002.

VanGuilder, H.D., Vrana, K.E., Freeman, W.M.: Twenty-five years of quantitative PCR for gene expression analysis. Biotechniques 44: 619, 2008.

Wang, H., Xu, Q., Kong, Y.H., Chen, Y., Duan, J.Y., Wu, W.H., Chen, Y.F.: Arabidopsis WRKY45 transcription factor activates PHOSPHATE TRANSPORTER1;1 expression in response to phosphate starvation. - Plant Physiol. 164: 2020-2029, 2014.

Xia, W., Z. Liu, Y. Yang, Y. Xiao, Mason A.S., Zhao, S., Ma, Z.: Selection of reference genes for quantitative real-time PCR in Cocos nucifera during abiotic stress. - Botany $\mathbf{9 2}$ : 179-186, 2013.

Xu, M., Zhang, B., Su, X., Zhang, S., Huang, M.: Reference gene selection for quantitative real-time polymerase chain reaction in Populus. - Anal. Biochem. 408: 337-339, 2011.

$\mathrm{Xu}, \mathrm{X}$., Chen, C., Fan, B., Chen, Z.: Physical and functional interactions between pathogen-induced Arabidopsis WRKY18, WRKY40, and WRKY60 transcription factors. Plant Cell 18: 1310-1326, 2006.

Zhang, L., Zhang, C., Wu, P.Z., Chen, Y.P., Li, M., Jiang, H., $\mathrm{Wu}$, G.: Global analysis of gene expression profiles in physic nut (Jatropha curcas L.) seedlings exposed to salt stress. - PLoS ONE. 9: e97878, 2014.

Zhong, C., Zhang, Y., Chen, Y., Jiang, Q., Chen, Z., Liang, J., Pinyopusarerk, K., Franche, C., Bogusz, D.: Casuarina research and applications in China. - Symbiosis 50: 107$114,2010$. 